\title{
PREVALENCE, PATTERN, AND DETERMINANT OF SEX PREFERENCE IN INDIA: EVIDENCE FROM INDIA HUMAN DEVELOPMENT SURVEY-II (2011-12)
}

\author{
Manoj Dakua $1 \bowtie$ (D), Bappa Sarkar ${ }^{2} \bowtie$ \\ ${ }^{1}$ Research Scholar, International Institute for population sciences, Mumbai, India. \\ ${ }^{2}$ Assistant professor, Dinhata College, West Bengal, India.
}

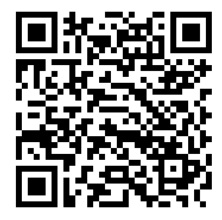

Received 16 October 2021

Accepted 16 November 2021

Published 30 November 2021

\section{CorrespondingAuthor}

Manoj Dakua, manoj07@iipsindia.ac.in

DOI

10.29121/granthaalayah.v9.i11.2021 .4382

Funding: This research received no specific grant from any funding agency in the public, commercial, or not-for-profit sectors.

Copyright: (C) 2021 The Author(s). This is an open access article distributed under the terms of the Creative Commons Attribution License, which permits unrestricted use, distribution, and reproduction in any medium, provided the original author and source are credited.

\section{ABSTRACT}

Sex preference is highly dominated in India and its adjacent South Asian countries. The present study examines the pattern, prevalence, and determinants of sex preference for an extra child at India's national and regional levels. For this study, we have utilized the secondary data of the Indian Human Development Survey-II. Bivariate analysis and multivariate logistic regression analysis were carried out to understand the difference of sex preference for an extra child by selected background variable- prevalence of sex preference almost $40 \%$ in India. Sex preference is higher among women who have three alive children, where the son's preference is more who have at least four living children. Son preference is decreasing with the increase of women's educational levels. On the contrary, sex preference is more among lower age at marriage. The odds of sex preference are higher among those above bachelor's degrees than those with no formal education. On the contrary, sons' preference is higher who completed their primary education than those who have no education. Sex preference, especially son's preference, directly or indirectly affects on sex ratio. Therefore, Government should focus on an awareness program and make some policies for a venerable woman identified in this study.

Keywords: Sex Preference, Women, Gender, India

\section{INTRODUCTION}

The sex ratio is a useful and practical measure for determining the relative excess or deficiency of males and females in a population at any given period. Over the past 100 years of the Census of India, the gender gap is prevalent and reflects the nationwide household-level decision Pande et al. (2006). Sex preference is broadly dominated in India and other South Asian countries Arnold et al. (2002), Clark (2000), Barman and Sahoo (2021). Sex preference refers to the desire small number of a child of a particular sex Kulkarni (1999). Son preference is one of the fearful traditions in India, which can be a common attribute of couples, who have an only girl child, is associated with the disregarded and dead of millions of females through the infanticide, under nutritional status, lack of medical care, and sex-selective abortion Arnold et al. (2002), Mitra (2014). Sex preference is one of the significant cortical factors which reflect the fertility behaviour of couples and its effects on the sex composition of the family Clark (2000), mortality Arnold (2002) and demographic transition, population composition, and future fertility Aksan (2017). In the previous studies, it is evident that couples with strong son references may provide poor health services and necessary food to daughters; 
this practice may increase daughter childhood mortality and affect children's survival sex composition later Bardhan (1974), Basu (1989), Sen and Sengupta (1983). Others have documented the role of son preference in slowing the transition to low fertility Arnold et al. (1998), Das et al. (1997), Leone et al. (2003). As per the Indian census, the child sex ratio showing very low in some states, namely, Haryana (834), Punjab (846), Jammu and Kashmir (862), Delhi (871), Rajasthan (888), Uttarakhand (890), Gujarat (890), Maharashtra (894), Uttar Pradesh (902), Himachal Pradesh (909). In India, the son plays a vital role in religious rites, providing financial protection to the family while the daughter drains finance by the dowries Pande et al. (2006). On the contrary, cultural restriction of Indian women and domination of men also have a significant role in the prevalence of son preference for an extra child Pande and Astone (2007). The sex preference of an extra child varies not only at the national level; it also varied state level Bongaarts (2013). In northern India, sex preference is high among large family sizes and belongs to socio-economically backward classes Clark (2000). Some studies documented that individual and household factors affect son preference Bharati et al. (2011). Some studies suggest that social factors play a significant role and individual \& household factors Pande and Astone (2007).

Though most of the studies focused on son preference, limited studies that focus on prevalence, pattern, and determinate of sex preference are stated of son preference at the state level. Therefore, the present study examines the pattern and prevalence of sex preference for an extra child at India's national and regional levels. Further, the present study explores the demographic and socio-economic determinants that significantly affect sex preference for an extra child in India.

\section{DATA AND METHOD}

\subsection{DATA}

For the present study, we have utilized the secondary data of the second round of the Indian Human Development Survey 2011-12. Indian Human Development Survey (IHDS) is a nationally representative, multi-topic survey, large scale across India. The IHDS is a collaborative research program conducted by the researcher from the National Council of Applied Economic Research (NCAER) and the University of Maryland Desai and Vanneman (2015). IHDS includes information about direct information on sex preference for an extra child, income and employment data, health services and expenditure, sexual harassment, gender relations, and other contextual social and economic research topics. The data quality of this survey has always match with other large-scale surveys like National Family Health Survey (NFHS) and National Sample Survey (NSS) Desai and Andrist (2010).

\subsection{SAMPLE SIZE AND THE OUTCOME VARIABLE}

The second round of IHDS was conducted during 2011-12. The total sample size was 42,152 households collected from 1420 villages and 1042 urban areas with a more than 95 percent response rate. This present study focuses only the eligible women. Eligible woman record file used for analysis, and in this present study, the total sample size of 15 to 49 years women is 39,459 in India. This study measures the sex preference for an extra child. In IHDS, every eligible woman asked a question, which is "if you happened to have one more child, would you want that extra child to be a boy or a girl" and respondents were given the option to answer, 'boy' 'girl' and 'no preference.' Those respondents answered they want a boy or girl, and they are considered as a sex preferred. 


\subsection{EXPLANATORY VARIABLES}

Some socio-economic and demographic predictor variables such as educational level, age group, currently working status for pay/wages, who chose their husband, religion, caste category, spouse education, type of resident, zone, and continuous variable such as the number of alive children included in the present study. In IHDS, educational level and spouse education collected in single years of schooling, further these variables categories into six categories such as zero years as a no education, one to four years as primary education, five to ten years as secondary education, eleven to twelve as a higher secondary, thirteen to fifteen as bachelors and above fifteen as an above bachelor. Dependent variable further categorized into categories such as sex preference for who answered they want a boy or girl and no preference for answering no preference. Further, the dependent variable categorizes into two categories: boys and girls here, with no preference excluded.

\subsection{ANALYTICAL APPROACH}

Bivariate analysis and multivariate logistic regression analysis were carried out to understand the difference in sex preference for an extra child by selected background variables and fulfill this present research objective. Chi-squared analyses were utilized to know the bivariate difference and association of sex preference for an extra child among selected background characteristics. When independent variables included numerical and categorical, and the outcome variable is dichotomous, binary logistic regression was applied. The advantage of logistic regression is that there is no need for any assumption concerning the distribution of independent variables, and the coefficient can be described as an odd ratio. The binary response for sex preference (no preference vs. sex preference and girl preference vs. boy preference) was related to a set of categorical predictors, $\mathrm{X}$ (educational level, age group, currently working status for pay/wages, who chose their husband, number of alive children, religion, caste category, spouse education, type of resident, zone) by a logit link function;

$$
\operatorname{logit}\left(\pi_{\mathrm{ij}}\right)=\log \left[\frac{\pi_{i}}{1-\pi i}\right]=\beta_{0}+\beta(\mathrm{X})+\epsilon
$$

The probability of sex preference and son preference is taken as $\pi \mathrm{i}$; the parameter $\beta 0$ estimates the odd of sex preference and son preference. Parameter $\beta$ accounts for maximum likelihood, and the differential log odd of sex preference and son preference correlated with predictors, X compare to the reference category. Statistical analysis was carried out by using IBM SPSS version 20.

\section{RESULTS}

\subsection{DESCRIPTIVE INFORMATION OF RESPONDENTS}

Table 1 shows the proportional distribution of eligible women by selected background characteristics in the India Human Development Survey 2011-12. The majority of women were from no preference (65.9\%), followed by boys' preference $(27.4 \%)$ and girls' preference (6.7\%). Nearly one-third of women have two living children, and one-fifth of women have four or more than four living children and have three living children, followed by having one living child. Very few women were from in the age group, 15-19 and more or less same from others age group. Two-fifths of women had completed their secondary education followed by no 
education (36.5\%), where about fifty percent of women spouses have secondary education. During the second round of the India Human Development Survey, threefifths of the women were currently working for pay/wages, and the age at marriage below 23 was very high. About 73 percent of women chose their husbands by parents/ other relatives alone, and most women from Hindu (82.2\%) religion followed by Muslims. One-fifth of women were from the Northern and Southern parts, followed by the central part of India, and most women were residing in rural areas.

Table 1 Percentage distribution of eligible women who had given their sex preference for extra child, India, IHDS- 2011-12

\begin{tabular}{|c|c|c|c|c|c|}
\hline $\begin{array}{l}\text { Background } \\
\text { characteristics }\end{array}$ & $\begin{array}{c}\text { Percentage } \\
(\%)\end{array}$ & $\begin{array}{c}\text { Number of } \\
\text { observation } \\
\text { (n) }\end{array}$ & $\begin{array}{c}\text { Background } \\
\text { characteristics2 }\end{array}$ & $\begin{array}{c}\text { Percentage } \\
(\%)\end{array}$ & $\begin{array}{c}\text { Number of } \\
\text { observation } \\
\text { (n) }\end{array}$ \\
\hline $\begin{array}{l}\text { Sex preference } \\
\text { for extra child }\end{array}$ & & & $\begin{array}{c}\text { Currently } \\
\text { working for } \\
\text { pay/wages }\end{array}$ & & \\
\hline Boy & 27.4 & 9203 & No & 36.44 & 4948 \\
\hline Girl & 6.7 & 2262 & Yes & 63.56 & 8629 \\
\hline No preference & 65.9 & 22118 & Age at marriage & & \\
\hline $\begin{array}{l}\text { Number of alive } \\
\text { children }\end{array}$ & & & Below 18 & 44.9 & 15073 \\
\hline 0 & 6.7 & 2251 & $18-22$ & 45 & 15128 \\
\hline 1 & 15.9 & 5341 & 23-27 & 8.5 & 2866 \\
\hline 2 & 34.1 & 11457 & Above 27 & 1.5 & 516 \\
\hline 3 & 22.4 & 7533 & $\begin{array}{c}\text { Who chose your } \\
\text { husband }\end{array}$ & & \\
\hline 4 or above & 20.8 & 7001 & $\begin{array}{c}\text { Respondent } \\
\text { herself }\end{array}$ & 5 & 1687 \\
\hline $\begin{array}{c}\text { Educational } \\
\text { level }\end{array}$ & & & $\begin{array}{l}\text { Respondent and } \\
\text { parents/ other } \\
\text { relatives together }\end{array}$ & 22.2 & 7464 \\
\hline No education & 36.5 & 12260 & $\begin{array}{l}\text { Parents/ other } \\
\text { relatives alone }\end{array}$ & 72.4 & 24321 \\
\hline Primary & 7.3 & 2438 & others & 0.2 & 73 \\
\hline Secondary & 42.2 & 14177 & Religion & & \\
\hline $\begin{array}{l}\text { Higher } \\
\text { secondary }\end{array}$ & 7.1 & 2394 & Hindu & 82.2 & 27622 \\
\hline Bachelors & 4.9 & 1657 & Muslim & 11.6 & 3896 \\
\hline $\begin{array}{c}\text { Above } \\
\text { bachelors }\end{array}$ & 2 & 657 & Christian & 2.2 & 749 \\
\hline Age group & & & Sikh & 2.4 & 818 \\
\hline 15-19 & 1.9 & 644 & Buddhist & 0.7 & 246 \\
\hline $20-24$ & 11.1 & 3721 & Jain & 0.2 & 78 \\
\hline $25-29$ & 16.1 & 5421 & Tribal & 0.4 & 133 \\
\hline $30-34$ & 15.8 & 5317 & Others & 0.1 & 30 \\
\hline $35-39$ & 16.5 & 5550 & None & 0 & 11 \\
\hline $40-44$ & 14.8 & 4980 & Caste category & & \\
\hline $45-49$ & 13.6 & 4560 & Brahmin & 5.3 & 1765 \\
\hline Above 49 & 10.1 & 3390 & $\begin{array}{l}\text { Forward/general } \\
\text { (except Brahmin) }\end{array}$ & 23.7 & 7957 \\
\hline $\begin{array}{c}\text { Spouse } \\
\text { education }\end{array}$ & & & $\begin{array}{c}\text { Other backward } \\
\text { classes }\end{array}$ & 40.4 & 13564 \\
\hline No education & 19 & 7521 & Scheduled castes & 21.2 & 7129 \\
\hline Primary & 8.1 & 3190 & Scheduled tribe & 7.9 & 2650 \\
\hline
\end{tabular}




\begin{tabular}{cccccc}
\hline $\begin{array}{c}\text { Secondary } \\
\text { Higher }\end{array}$ & 46.1 & 18221 & Others & 1.4 & 463 \\
secondary & 9.5 & 3770 & Zone & & \\
$\begin{array}{c}\text { Bachelors } \\
\text { Above }\end{array}$ & 7.3 & 2902 & North & 23.8 & 7978 \\
$\begin{array}{c}\text { bachelors } \\
\text { Type of } \\
\text { residence }\end{array}$ & 9.9 & 3919 & Central & 18.6 & 6250 \\
Rural & 65.3 & 21925 & North east & 16.7 & 5607 \\
Urban & 34.7 & 11658 & West & 14.8 & 4965 \\
& & & South & 22.1 & 7433
\end{tabular}

\subsection{DIFFERENCE IN SEX PREFERENCE}

The bivariate differentials of sex preference for an extra child among reproductive women during 2011-12 by selected background characteristics are exhibited in Table 2. Around 37 percent of the reproductive women were giving their sex preference for extra children in the second round of IHDS; however, it was highest among those with three alive children followed by one alive child. Sex preference for an extra child in the second round of IHDS was more than 38 percent among those who did primary education followed by no formal educated woman. On the contrary, sex preference was higher among those women spouses have no formal education. In the second round of the IHDS survey, the highest sex preference for the extra child was women above 49 years, followed by in the age group 15-19, sex preference was higher among women currently working for pay/wages $(40.2 \%)$. There is a negative relationship between sex preference for extra child and the age at marriage of women. Prevalence of sex preference is higher among age at marriage below 18 years woman. More than two-fifth of women have a sex preference for an extra child who chose their husband by herself. More women from Tribal/Others/Buddhist religions given their sex preference for an extra child during IHDS-II. However, sex preference was least by Sikh (21\%) women. Castewise sex preference revealed that the highest sex preference for an extra child was by others (50.3\%) followed by scheduled tribe (41.2\%), While it was lower among Brahmin caste categories. Those women residing in rural areas in India during the second round of the IHDS survey, their prevalence of sex preference is higher than urban areas. There were differentials in sex preference for an extra child by region of residence and showed that the sex preference was higher for women residing in the west region (48.5\%) followed by the south (43.3\%). In comparison, it was lower among women from the central region $(21.5 \%)$.

\subsection{DIFFERENCE IN SON'S AND GIRL'S PREFERENCE}

Table 3 was showing the bivariate differentials of son's and girl's preferences for an extra child among women by different socio-economic and demographic characteristics. During the second round of the IHDS survey, son preference (80.9\%) is highly present, while girl's preference was relatively low (19.06\%) in India. Son's preference is higher among women with at least four alive children, followed by women with no alive child; however, girls' preference is higher among women with one alive child. Son's preference and women's education have negative relation, but woman education positively relates to girls' preference. During the IHDS-II survey, the son's preference is higher among women with no formal education, and girls' preference is higher among women with above bachelor's degrees. Higher son preferences were prevalent among women in the age group above 49 years, 
followed by women in the age group 15-19, and higher girls preferred women in the age group 20-24. Son's and girl's preference for an extra child does not look different by currently working for pay/wages status of women during the second round of IHDS survey in India. Nearly 82 percent of women who chose their husband by Parents/ other relatives alone prefer sons for an extra child. More than four-fifths of women who belong to others/Hindu/Sikhs preferred sons for an extra child, and girls' preference was higher among women who belong to none, followed by the Jain community. Caste-wise sons and girls preference revealed that the higher son's preference by scheduled caste, while girl's preference was higher by others category. Sons' preference was higher for women whose husbands had no formal education, while girls' preference was higher with women's spouse has bachelor's degree. Women belonging to rural areas have higher son preference but girls' preference for higher in urban areas in India, during the second round of the IHDS survey. There were differences in son's and girl's preferences by region of residence. Son's preference was higher among women residing in the central $(89.4 \%)$ part, while girls' preference was higher in India's northern (23\%) part.

\begin{tabular}{|c|c|c|c|c|c|}
\hline $\begin{array}{c}\text { Background } \\
\text { characteristics }\end{array}$ & Yes & No & Background characteristics & Yes & No \\
\hline Number of alive children & & & Age at marriage & & \\
\hline 0 & 32.8 & 67.2 & Below 18 & 37.4 & 62.6 \\
\hline 1 & 38 & 62 & $18-22$ & 36.5 & 63.5 \\
\hline 2 & 36.2 & 63.8 & $23-27$ & 32.5 & 67.5 \\
\hline 3 & 40.2 & 59.8 & Above 27 & 29.4 & 70.6 \\
\hline 4 or above & 33.4 & 66.6 & Who chose your husband & & \\
\hline Educational level & & & Respondent herself & 40.8 & 59.2 \\
\hline No education & 37.4 & 62.6 & $\begin{array}{l}\text { Respondent and parents/ other } \\
\text { relatives together }\end{array}$ & 34.1 & 65.9 \\
\hline Primary & 38.3 & 61.7 & Parents/ other relatives alone & 30.2 & 69.8 \\
\hline Secondary & 36.2 & 63.8 & others & 19.9 & 80.1 \\
\hline Higher secondary & 34.2 & 65.8 & Religion & & \\
\hline Bachelors & 34.6 & 65.4 & Hindu & 36.9 & 63.1 \\
\hline Above bachelors & 34.4 & 65.6 & Muslim & 33 & 67 \\
\hline Age group & & & Christian & 39.1 & 60.9 \\
\hline $15-19$ & 40.5 & 59.5 & Sikh & 21 & 79 \\
\hline $20-24$ & 35.5 & 64.5 & Buddhist & 50.4 & 49.6 \\
\hline $25-29$ & 39.1 & 60.9 & Jain & 28.8 & 71.2 \\
\hline $30-34$ & 36.5 & 63.5 & Tribal & 65.9 & 34.1 \\
\hline $35-39$ & 36.8 & 63.2 & Others & 62.9 & 37.1 \\
\hline $40-44$ & 34.4 & 65.6 & None & 17.2 & 82.8 \\
\hline $45-49$ & 35.9 & 64.1 & Caste category & & \\
\hline Above 49 & 100 & 0 & Brahmin & 27.3 & 72.7 \\
\hline Spouse education & & & Forward/general (except Brahmin) & 35.8 & 64.2 \\
\hline No education & 33.4 & 66.6 & Other backward classes & 35.6 & 64.4 \\
\hline Primary & 32.3 & 67.7 & Scheduled castes & 38.7 & 61.3 \\
\hline Secondary & 31.7 & 68.3 & Scheduled tribe & 41.2 & 58.8 \\
\hline Higher secondary & 29 & 71 & Others & 50.3 & 49.7 \\
\hline Bachelors & 31.6 & 68.4 & Zone & & \\
\hline Above bachelors & 29.3 & 70.7 & North & 32.7 & 67.3 \\
\hline Type of residence & & & Central & 21.5 & 78.5 \\
\hline
\end{tabular}




\begin{tabular}{|ccccccc}
\hline Rural & 37.7 & 62.3 & East & 37.4 & 62.6 \\
\hline Urban & 34.2 & 65.8 & North east & 42.1 & 57.9 \\
\hline $\begin{array}{c}\text { Currently working for } \\
\text { pay/wages }\end{array}$ & & & West & 48.5 & 51.5 \\
\hline No & 35.4 & 64.6 & South & 43.3 & 56.7 \\
Yes & 40.2 & 59.8 & & & \\
\hline
\end{tabular}

\subsection{FACTOR ASSOCIATED WITH SEX PREFERENCE IN INDIA}

Table 4 shows the results of the multivariate analysis of sex preference. The number of alive children, educational level, age of women, working status of women, age at marriage, religion, caste categories, spouse education, type of resident, region of residence significantly determine sex preference for an extra child in India. The likelihood of sex preference is higher among women who have three alive children, whereas son preference is 61 percent lower among women with one alive child. The effect of education on sex preference for an extra child was evident among Indian women. The odds of sex preference are higher among women who completed a graduate degree (OR=1.29 95\% CI=1.289-1.297), while the son preference is higher for women who have completed primary education $(\mathrm{OR}=1.14$ 95\% CI= 1.1371.146). The likelihood of sex preference was higher among women aged 25-29 years than women aged 15-19 years of age, but son preference was higher among women aged 15-19 years. Currently, working for pay/wages does not affect son preference compare to girl preference. Still, for women who are currently working for pay/wages, their likelihood of sex preference is higher (OR=0.947 95\% CI= 0.9460.948 ) than women not working for pay/wages. The effect of age at marriage is a significant factor affecting sex preference for an extra child.

The odds of sex preference and son preference were lower among women above 27 years of age. The odds of son preference were higher for women who chose their husbands by parents/ other relatives together $(\mathrm{OR}=1.53995 \% \mathrm{CI}=1.533$ 1.545). Those women belong to other religious categories, their sexual preference is three times, and son preference is four times higher than that of Hindu religions. The likelihood of sex preference and son preference was higher than those of other caste categories compared to Brahmins. Spouse education negatively impacted sex preference, but son preference was higher among women spouses above bachelor's degree $(\mathrm{OR}=1.19795 \% \mathrm{CI}=1.192-1.202)$ than no formal education. The odds of sex preference and son preference were lower for women residing in urban areas than rural areas. The odds of sex preference are higher in the western region. Son preference was three (OR=3.102 95\% CI=3.088-3.115) times higher in the central region; on the contrary, sex preference is lower in the northern region of India.

\begin{tabular}{|c|c|c|c|c|c|}
\hline $\begin{array}{l}\text { Background } \\
\text { characteristics }\end{array}$ & Boys & Girls & Background characteristics2 & Boys & Girls \\
\hline Number of alive children & & & Age at marriage & & \\
\hline 0 & 84.2 & 15.8 & Below 18 & 83.1 & 16.9 \\
\hline 1 & 69.9 & 30.1 & $18-22$ & 78.8 & 21.2 \\
\hline 2 & 78.7 & 21.3 & $23-27$ & 72.5 & 27.5 \\
\hline 3 & 83 & 17 & Above 27 & 60.7 & 39.3 \\
\hline 4 or above & 88.9 & 11.1 & Who chose your husband & & \\
\hline Educational level & & & Respondent herself & 73.2 & 26.8 \\
\hline No education & 84.8 & 15.2 & $\begin{array}{l}\text { Respondent and parents/ other } \\
\text { relatives together }\end{array}$ & 79.1 & 20.9 \\
\hline
\end{tabular}




\begin{tabular}{|c|c|c|c|c|c|}
\hline Primary & 82 & 18 & Parents/ other relatives alone & 81.4 & 18.6 \\
\hline Secondary & 78.7 & 21.3 & others & 78.6 & 21.4 \\
\hline Higher secondary & 72.4 & 27.6 & Religion & & \\
\hline Bachelors & 72.6 & 27.4 & Hindu & 81 & 19 \\
\hline Above bachelors & 62.5 & 37.5 & Muslim & 77.6 & 22.4 \\
\hline Age group & & & Christian & 68.4 & 31.6 \\
\hline $15-19$ & 85.6 & 14.4 & Sikh & 82.6 & 17.4 \\
\hline $20-24$ & 74.5 & 25.5 & Buddhist & 77.1 & 22.9 \\
\hline $25-29$ & 81.2 & 18.8 & Jain & 46 & 54 \\
\hline $30-34$ & 81.1 & 18.9 & Tribal & 78.1 & 21.9 \\
\hline $35-39$ & 79.9 & 20.1 & Others & 94.5 & 5.5 \\
\hline $40-44$ & 81.8 & 18.2 & None & 0 & 100 \\
\hline $45-49$ & 81 & 19 & Caste category & & \\
\hline Above 49 & 100 & 0 & Brahmin & 77.1 & 22.9 \\
\hline Spouse education & & & Forward/general (except Brahmin) & 77.5 & 22.5 \\
\hline No education & 85.1 & 14.9 & Other backward classes & 80.6 & 19.4 \\
\hline Primary & 83.1 & 16.9 & Scheduled castes & 83.3 & 16.7 \\
\hline Secondary & 79.4 & 20.6 & Scheduled tribe & 79.3 & 20.7 \\
\hline Higher secondary & 76.5 & 23.5 & Others & 79.2 & 20.8 \\
\hline Bachelors & 72.6 & 27.4 & Zone & & \\
\hline Above bachelors & 81.5 & 18.5 & North & 77 & 23 \\
\hline Type of residence & & & Central & 89.4 & 10.6 \\
\hline Rural & 82.1 & 17.9 & East & 82.2 & 17.8 \\
\hline Urban & 76.2 & 23.8 & North east & 65.5 & 34.5 \\
\hline $\begin{array}{l}\text { Currently working for } \\
\text { pay/wages }\end{array}$ & & & West & 79.6 & 20.4 \\
\hline No & 82.1 & 17.9 & South & 78.7 & 21.3 \\
\hline Yes & 82.9 & 17.1 & & & \\
\hline
\end{tabular}

\section{DISCUSSION AND CONCLUSION}

\subsection{DISCUSSION}

From the present study, it is found that there is a high sex preference for an extra child while there is a high literacy level (74.64\%) in India. There is a strong son preference all over India; on the contrary, girl's preference is very low in the Central part. The prevalence of son and girl preference for an extra child varies by different socio-economic and demographic backgrounds. The degree of dependence on any one of these may vary with other factors' absence and presence. Son preference is higher among women who have three alive children, those who completed primary education, those who were above 49 years, currently working for pay/wages, below 18 ages at marriage, those who chose their husband herself, belongs to tribal and others caste, the spouse has no formal education, residing in rural areas.

On the contrary, girl's preference for an extra child is higher among their counterparts. Similar to our study findings, previous studies have also emphasized the importance of literacy in reducing the son preference among women Robitaille (2013), Frempong and Codjoe (2017). The literacy rate plays a crucial role in lowering son preference for an extra child of women. Some previous studies have documented that sex-based discrimination of post-natal care is the main reason for higher child-daughter mortality Gupta (1987). Post-natal care leads to reducing the total number of females in the population Premi (2002). We found that women who have three alive child prevalence of son preference are 83 percent, whereas those 
with at least four alive child prevalence of son preference are 88.9 percent. It implies large-size families have a relatively stronger desire for sons. Our present study findings documented that the prevalence of son preference and odds is higher in rural India than in urban areas.

Along with the kinship system, the Indian agrarian economy plays a curtail role in internalize son preference Das et al. (2003). Almost seven in ten persons living in rural areas in India and depend on agriculture for their livelihood. Bestowed those men are more felt to agricultural work than women, a reference of sons is not astonishing. In terms of caste, scheduled caste and scheduled tribes have a stronger desire for sons than women from Brahmin. When making the region-wise comparison, women from Central and Eastern regions prefer sons more than those from Northern and Southern regions. Out of region, cultural and religious values play a crucial role in determining the cultural and social norms that influence sons' preference. Sons are significant in Hinduism and the major religions in India. Among Hindus, a deceased parent's soul can achieve heaven only if the person has a boy to light the exequial pyre, and salvation can be accomplished through sons who offer paternal worship Vlassoff (1990). Studies suggest that son preference is higher among Muslim women Murthy (1996) and Sikhs women's Gupta (1987), Sabherwal (2014) Our results suggest that urbanization and women's education level can notably reduce son preference. These factors may not combat the issue entirely. For example, according to the census of India, the sex ratio was 1058 females per 1000 males. Still, their child sex ratio was only 963 females per 1000 males, while the literacy rate varies high among both males and females in Kerala. Another microlevel study in urban Kolkata (census 2001) shows the child sex ratio was 923 females per 1000 males. These studies do not support the view that increase female literacy and urbanization can alone reduce son preference in India. Thus, it is evident that there are some factors beyond literacy and urbanization that determine India's son preference

Table 4 Odds ratios (with 95\% Confidence Interval) estimated from the binary logistic regression models showing factors associated with sex preference of extra children, India, IHDS- 2011-12

\begin{tabular}{|c|c|c|c|c|}
\hline & $\begin{array}{l}\text { No preference vs. } \\
\text { Sex preference } \\
\text { (both) }\end{array}$ & & $\begin{array}{c}\text { Girl's preference } \\
\text { vs. Son's } \\
\text { preference }\end{array}$ & \\
\hline Background characteristics & Odds & $95 \% \mathrm{CI}$ & Odds & $95 \% \mathrm{CI}$ \\
\hline \multicolumn{5}{|l|}{ Number of alive children } \\
\hline $0 @$ & 1 & & 1 & \\
\hline 1 & $1.304^{* * *}$ & $\begin{array}{l}1.301- \\
1.307\end{array}$ & $0.390^{* * *}$ & $\begin{array}{c}0.387- \\
0.392\end{array}$ \\
\hline 2 & $1.297^{* * *}$ & $\begin{array}{c}1.294- \\
1.300\end{array}$ & $0.544^{* * *}$ & $\begin{array}{c}0.542- \\
0.547\end{array}$ \\
\hline 3 & $1.542^{* * *}$ & $\begin{array}{c}1.538- \\
1.546\end{array}$ & $0.697^{* * *}$ & $\begin{array}{c}0.693- \\
0.701\end{array}$ \\
\hline 4 or above & $1.288^{* * *}$ & $\begin{array}{c}1.285- \\
1.292\end{array}$ & $0.935^{* * *}$ & $\begin{array}{c}0.929- \\
0.941\end{array}$ \\
\hline \multicolumn{5}{|l|}{ Educational level } \\
\hline No education@ & 1 & & 1 & \\
\hline Primary & $0.953^{* * *}$ & $\begin{array}{c}0.951- \\
0.955\end{array}$ & $1.141^{* * *}$ & $\begin{array}{l}1.137- \\
1.146\end{array}$ \\
\hline Secondary & $0.878^{* * *}$ & $\begin{array}{c}0.877- \\
0.879\end{array}$ & $0.994^{* * *}$ & $\begin{array}{c}0.992- \\
0.997\end{array}$ \\
\hline Higher secondary & $1.045^{* * *}$ & $\begin{array}{l}1.042- \\
1.048\end{array}$ & $0.896^{* * *}$ & $\begin{array}{c}0.892- \\
0.900\end{array}$ \\
\hline
\end{tabular}


Prevalence, Pattern, And Determinant of Sex Preference in India: Evidence from India Human Development Survey-II (2011-12)

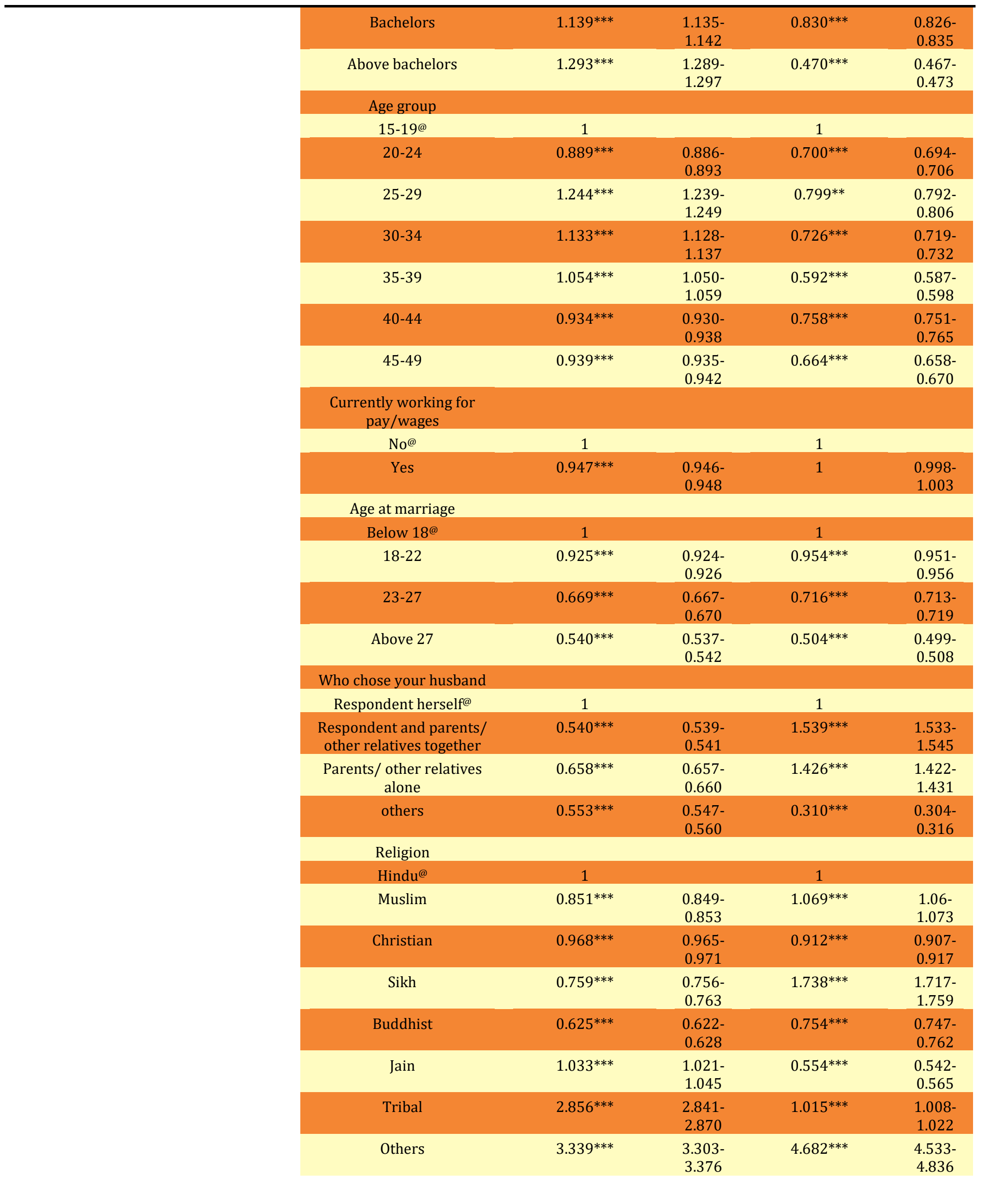




\begin{tabular}{|c|c|c|c|c|}
\hline None & $0.480^{* * *}$ & $\begin{array}{c}0.470- \\
0.489\end{array}$ & 0 & $\begin{array}{l}0.000- \\
0.000\end{array}$ \\
\hline \multicolumn{5}{|l|}{ Caste category } \\
\hline Brahmin@ & 1 & & 1 & \\
\hline $\begin{array}{c}\text { Forward/general (except } \\
\text { brahmin) }\end{array}$ & $1.013^{* * *}$ & $\begin{array}{l}1.010- \\
1.016\end{array}$ & $1.039^{* * *}$ & $\begin{array}{l}1.033- \\
1.046\end{array}$ \\
\hline Other backward classes & $0.931^{* * *}$ & $\begin{array}{l}0.928- \\
0.934\end{array}$ & $1.097^{* * *}$ & $\begin{array}{l}1.090- \\
1.104\end{array}$ \\
\hline Scheduled castes & $1.046^{* * *}$ & $\begin{array}{l}1.042- \\
1.049\end{array}$ & $1.356^{* * *}$ & $\begin{array}{l}1.347- \\
1.364\end{array}$ \\
\hline Scheduled tribe & $1.001^{* * *}$ & $\begin{array}{l}0.998- \\
1.005\end{array}$ & $1.021^{* * * *}$ & $\begin{array}{l}1.014- \\
1.028\end{array}$ \\
\hline Others & $1.354^{* * *}$ & $\begin{array}{l}1.347- \\
1.360\end{array}$ & $1.583^{* * *}$ & $\begin{array}{l}1.570- \\
1.597\end{array}$ \\
\hline \multicolumn{5}{|l|}{ Spouse education } \\
\hline No education@ & 1 & & 1 & \\
\hline Primary & $0.865^{* * *}$ & $\begin{array}{l}0.863- \\
0.866\end{array}$ & $1.048^{* * *}$ & $\begin{array}{l}1.044- \\
1.052\end{array}$ \\
\hline Secondary & $0.911^{* * *}$ & $\begin{array}{c}0.910- \\
0.912\end{array}$ & $0.710^{* * *}$ & $\begin{array}{c}0.708- \\
0.712\end{array}$ \\
\hline Higher secondary & $0.945^{* * *}$ & $\begin{array}{c}0.943- \\
0.948\end{array}$ & $0.784^{* * *}$ & $\begin{array}{c}0.781- \\
0.788\end{array}$ \\
\hline Bachelors & $0.939 * * *$ & $\begin{array}{c}0.937- \\
0.942\end{array}$ & $0.741^{* * *}$ & $\begin{array}{c}0.738- \\
0.745\end{array}$ \\
\hline Above bachelors & $0.784^{* * *}$ & $\begin{array}{l}0.782- \\
0.785\end{array}$ & $1.197^{* * *}$ & $\begin{array}{l}1.192- \\
1.202\end{array}$ \\
\hline \multicolumn{5}{|l|}{ Type of residence } \\
\hline Rural@ & 1 & & 1 & \\
\hline Urban & $0.809 * * *$ & $\begin{array}{c}0.808- \\
0.810\end{array}$ & $0.750^{* * *}$ & $\begin{array}{c}0.748- \\
0.752\end{array}$ \\
\hline \multicolumn{5}{|l|}{ Zone } \\
\hline North@ & 1 & & 1 & \\
\hline Central & $0.466^{* * *}$ & $\begin{array}{l}0.465- \\
0.467\end{array}$ & $3.102^{* * *}$ & $\begin{array}{l}3.088- \\
3.115\end{array}$ \\
\hline East & $1.086^{* * *}$ & $\begin{array}{l}1.084- \\
1.088\end{array}$ & $1.303^{* * *}$ & $\begin{array}{c}1.298- \\
1.308\end{array}$ \\
\hline North east & $1.209^{* * *}$ & $\begin{array}{l}1.205- \\
1.214\end{array}$ & $0.890^{* * *}$ & $\begin{array}{c}0.885- \\
0.896\end{array}$ \\
\hline West & $1.750^{* * *}$ & $\begin{array}{l}1.747- \\
1.754\end{array}$ & $1.408^{* * *}$ & $\begin{array}{c}1.403- \\
1.413\end{array}$ \\
\hline South & $1.734^{* * *}$ & $\begin{array}{l}1.732- \\
1.737\end{array}$ & $1.341^{* * *}$ & $\begin{array}{l}1.337- \\
1.346\end{array}$ \\
\hline
\end{tabular}

Note- Levels of significance: ${ }^{* *} \mathrm{P} \leq 0.05,{ }^{* * *} \mathrm{P} \leq 0.01$, outcome variable (no sex preference $=0$, sex preference $=1$; girls' preference $=0 \&$ sons $=1$ )

\subsection{CONCLUSION}

This article emphasizes the requirement of gender budgeting embodiment policies because it's a practical approach to diminishing gender disparities in all spheres of life and providing inclusive and sustainable development. The Government needs to introduce different awareness programs to change the perspective towards girl's child and son preference in Indian society. Sex preference plays a crucial role in shaping the sex distribution of the population. Religious practice, cultural values, and patriarchal society force women or families to seek a sex-selective abortion. The skewed sex ratio creates an entire gender issue in 
society. May values of girl's child in society improve by implementing gendersensitive policies at all levels.

\section{REFERENCES}

Aksan, A. M. (2017, April). Son Preference and the Demographic Transition. In PAA 2017 Annual Meeting. PAA.

Arnold, F., Choe, M. K., \& Roy, T. K. (1998). Son preference, the family-building process and child mortality in India. Population Studies, 52(3), 301-315. Retrieved from https://doi.org/10.1080/0032472031000150486

Arnold, F., Kishor, S., \& Roy, T. K. (2002). Sex - selective abortions in India. Population and development review, 28(4), 759-785. Retrieved from https://doi.org/10.1111/j.1728-4457.2002.00759.x

Bardhan, P. K. (1974). On life and death questions. Economic and Political Weekly, 1293-1304. Retrieved from https://www.jstor.org/stable/4363909

Barman, P., \& Sahoo, H. (2021). Sex preference in India: Trends, patterns and determinants. Children and Youth Services Review, 122, 105876. Retrieved from https://doi.org/10.1016/j.childyouth.2020.105876

Basu, Alaka Malwade(1989). "Is discrimination in food really necessary for explaining sex differentials in childhood mortality?." Population studies 43, no. 2: 193-210. Retrieved from https://doi.org/10.1080/0032472031000144086

Bharati, S., Shome, S., Pal, M., Chaudhury, P., \& Bharati, P. (2011). Is son preference pervasive in India?. Journal of Gender Studies, 20(3), 291-298. Retrieved from https://doi.org/10.1080/09589236.2011.593328

Bongaarts, J. (2013). The implementation of preferences for male offspring. Population and Development Review, 39(2), 185-208. Retrieved from https://doi.org/10.1111/j.1728-4457.2013.00588.x

Clark, S. (2000). Son preference and sex composition of children: Evidence from India. Demography, 37(1), 95-108. Retrieved from https://doi.org/10.2307/2648099

Das Gupta, M., \& Mari Bhat, P. N. (1997). Fertility decline and increased manifestation of sex bias in India. Population Studies, 51(3), 307-315. Retrieved from https://doi.org/10.1080/0032472031000150076

Das Gupta, M., Zhenghua, J., Bohua, L., Zhenming, X., Chung, W., \& Hwa-Ok, B. (2003). Why is son preference so persistent in East and South Asia? A cross-country study of China, India and the Republic of Korea. The Journal of Development Studies, $\quad 40(2), \quad 153-187 . \quad$ Retrieved from https://doi.org/10.1080/00220380412331293807

Desai, S., \& Andrist, L. (2010). Gender scripts and age at marriage in India. Demography, 47(3), 667-687. Retrieved from https://doi.org/10.1353/dem.0.0118

Desai, S., \& Vanneman, R. (2015). India human development survey-ii (ihds-ii), 2011-12. Ann Arbor, MI: Inter-university Consortium for Political and Social Research.

Frempong, G. A., \& Codjoe, S. N. A. (2017). Sex preferences for children in Ghana: the influence of educational attainment. Journal of Population Research, 34(4), 313-325. Retrieved from https://doi.org/10.1007/s12546-017-9188-1 
Gupta, M. D. (1987). Selective discrimination against female children in rural Punjab, India. Population and development review, 77-100. Retrieved from https://doi.org/10.2307/1972121

Gupta, M. D. (1987). Selective discrimination against female children in rural Punjab, India. Population and development review, 77-100. Retrieved from https://doi.org/10.2307/1972121

Kulkarni, P. M. (1999). Gender preference contraceptive prevalence: evidence of regional variations. Economic and Political Weekly, 3058-3062. https://www.jstor.org/stable/4408537

Leone, T., Matthews, Z., \& Zuanna, G. D. (2003). Impact and determinants of sex preference in Nepal. International family planning perspectives, 69-75. Retrieved from https://doi.org/10.2307/3181060

Mitra, A. (2014). Son preference in India: Implications for gender development. Journal of Economic Issues, 48(4), 1021-1037. https://www.tandfonline.com/doi/abs/10.2753/JEI0021-3624480408

Murthy, R. K. (1996). Fighting female infanticide by working with midwives: an Indian case study. Gender \& Development, 4(2), 20-27. Retrieved from https://doi.org/10.1080/741922015

Pande, R. P., \& Astone, N. M. (2007). Explaining son preference in rural India: the independent role of structural versus individual factors. Population Research and Policy Review, 26(1), 1-29. Retrieved from https://doi.org/10.1007/s11113-006-9017-2

Pande, R., Malhotra, A., Mathur, S., Mehta, M., Malhotra, A., Lycette, M. A., ... \& Lary, H. (2006). Son preference and daughter neglect in India.

Pande, R., Malhotra, A., Mathur, S., Mehta, M., Malhotra, A., Lycette, M. A., ... \& Lary, H. (2006). Son preference and daughter neglect in India.

Premi, M. K. (2002), January). The girl child: Some issues for consideration. In Symposium on sex ratio in India, Mumbai, International Institute for Population Sciences.

Robitaille, M. C. (2013). Determinants of stated son preference in India: are men and women different?. The Journal of Development Studies, 49(5), 657-669. Retrieved from https://doi.org/10.1080/00220388.2012.682986

Sabherwal, S. K. (2014). An Exploration of Son Preference and the Treatment of Daughters among Punjabi Sikhs in Northern California (Doctoral dissertation, Johns Hopkins University) https://www.proquest.com/openview/315d509ed08b169158e5554cfcec 1f1a/1?pq-origsite $=$ gscholar\&cbl=18750\&diss $=y$

Sen, A., \& Sengupta, S. (1983). Malnutrition of rural children and the sex bias. Economic and political weekly, 855-864. https://www.jstor.org/stable/4372128

Vlassoff, C. (1990). The value of sons in an Indian village : How widows see it. Population Studies, 44(1), 5-20. Retrieved from https://doi.org/10.1080/0032472031000144356 